\title{
IN-VITRO EFFECT OF THE METHANOLIC EXTRACT OF Momordica charantia ON HATCHING OF EGGS OF Haemonchus sp.
}

\author{
EFECTO IN-VITRO DEL EXTRACTO METANÓLICO DE \\ Momordica charantia SOBRE LA ECLOSIÓN DE HUEVOS \\ DE Haemonchus sp.
}

Dumar Alexander JARAMILLO' ${ }^{1}$, Adolfo VÁSQUEZ TRUJILLO² and Lida Carolina LESMES RODRÍGUEZ ${ }^{3}$

JOURNAL VITAE

School of Pharmaceutical and Food Sciences ISSN 0121-4004 | ISSNe 2145-2660 University of Antioquia Medellin, Colombia

Filliations

${ }^{1}$ Faculty of Agricultural Sciences and Natural Resources, Animal Sciences School, Universidad de los Llanos, Km 12 vía Puerto López, Villavicencio, Colombia; $\mathrm{PhD}$ (c)

${ }^{2}$ School of Health Sciences. Universidad de los Llanos, Km 12 vía Puerto López,

Villavicencio, Colombia; PhD(c).

${ }^{3}$ Faculty of Sciences and Engineering, Department of Biology and Chemistry, Universidad de los Llanos, Km 12 vía Puerto López, Villavicencio, Colombia M. Sc.

*Corresponding Dumar Alexander Jaramillo Hernández dumar.jaramillo@unillanos.edu.co

Received: 7 February 2021 Accepted: 30 March 2021 Published: 9 April 2021

\begin{abstract}
Background: Endoparasitism, particularly infections by gastrointestinal nematodes (e.g., Haemochus sp.), has been associated with economic losses within sheep production systems in tropical regions. Thus, implementing therapeutic alternatives that are environmentally sustainable is essential for parasite integral control programs. Objectives: Evaluate in-vitro the effect of Momordica charantia methanolic extract on the Haemonchus sp. eggs' hatching process. Methods: Nematode eggs were retrieved from experimentally infected sheep and exposed to $10,20,40,80$, and $160 \mathrm{mg} / \mathrm{mL}$ of methanolic extract of $M$. charantia. Hatching percentages were recorded from five replicates, and $\mathrm{CL}_{50}$ and $\mathrm{CL}_{90}$ were estimated through Probit regression analysis. Results: A significant effect on the hatching percentages were observed, from $24.2 \%$ up to $84.6 \%$ inhibition $\left(p<0.05\right.$ ). The $L C_{50}$ and $\mathrm{LC}_{90}$ estimated were $52.2 \mathrm{mg} / \mathrm{mL}(95 \% \mathrm{Cl} 37.87-63.22)$ and $201.45 \mathrm{mg} / \mathrm{mL}(95 \% \mathrm{Cl} 186.01-221.89)$, respectively. Utilizing a preliminary phytochemical analysis, potential antihelmintic compounds such as alkaloid, triterpenes, and anthracenic glycosides groups were identified in the methanolic extract. Conclusions: In the in-vitro test, the methanolic extract of $M$. charantia was effective in inhibiting the hatching of Haemonchus sp., which is important to promote other bio-guided fractionation studies of this plant on different life stages of $\mathrm{H}$. contortus, this being a plant species widely adapted to the conditions of the piedmont (foothills) of Meta, Colombia.
\end{abstract}

Keywords: haemonchosis, phytotherapy, sheep farming. 


\section{RESUMEN}

Introducción: El endoparasitismo, particularmente las infecciones causadas por nematodos gastrointestinales (p. ej., Haemonchus sp.), ha sido asociado con pérdidas económicas en los sistemas de producción ovina de los países del trópico. Por lo tanto, es esencial la implementación de alternativas terapéuticas sostenibles para el ambiente con el fin de efectuar programas de control integrado del parásito. Objetivos: Evaluar el efecto in-vitro de los extractos metanólicos de M. charantia sobre el proceso de eclosión de los huevos de Haemonchus sp. Métodos: Los huevos derivados de un ovino monoinfestado se expusieron a concentraciones de 10,20,40, 80 y $160 \mathrm{mg} / \mathrm{mL}$ del extracto metanólico de $M$. charantia. Se registraron los porcentajes de eclosión de cinco réplicas, y la obtención de $\mathrm{CL}_{50}$ y $\mathrm{CL}_{90}$ se realizó a través de regresión lineal por el método Probit. Resultados: Se observó un efecto significativo en los porcentajes de eclosión; una inhibición desde 24.2\% hasta 84.6\% ( $p<0.05)$. Finalmente se estimaron $\mathrm{CL}_{50}$ y $\mathrm{CL}_{90}$ de $52.2 \mathrm{mg} / \mathrm{mL}$ (95\% IC 37.87-63.22) y 201.45 mg/mL (95\%IC 186.01-221.89), respectivamente. Así mismo, utilizando un análisis fitoquímico preliminar; en el extracto metanólico de $M$. charantia se identificaron compuestos antihelmínticos potenciales, tales como alcaloides, triterpenos, y glucósidos antracénicos. Conclusiones: En las pruebas invitro, el extracto metanólico de M. charantia fue eficaz para inhibir la eclosión de Haemonchus sp., lo cual es importante para promover otros estudios de fraccionamiento bio-guiados de esta planta sobre diferentes estadios de vida de $H$. contortus, siendo esta una especie vegetal ampliamente adaptada a las condiciones del piedemonte del Meta, Colombia.

Palabras clave: hemoncosis, fitoterapia, ovinocultura.

\section{INTRODUCTION}

The infestation by nematodes of the genus Haemonchus is a very relevant problem in small ruminant livestock production in tropical countries. This disease causes weight loss, immunosuppression, and gastroenteritis-associated malabsorption syndrome that affect the animals' welfare and normal development. Else, causing significant economic losses in the sheep production system due to both the effect on product yield and reproduction (1-5).

Gastrointestinal nematodes of the genus Haemonchus are hematophagous parasites and are the primary pathogen agent in the ruminants abomasum (6). Adult parasites of the $H$. contortus, $H$. placei, and $H$. similis the species can consume up to $0.05 \mathrm{~mL}$ of blood/day from their host, having a high clinical impact (7). The parasite sexual reproduction takes place in a natural host life cycle. Females are prolific, laying up to 10,000 eggs/day (pre-patent period of 3-5 weeks), which leads to a large number of infective and pre-infective forms of the parasite in the grasslands (eggs and L1, L2, and L3) (8). According to Stromberg and Gasbarre (9), the Haemonchus sp. larvae with infective capacity (L3) migrate from feces to forage approximately seven days post-hatch at $23{ }^{\circ} \mathrm{C}$ and $65 \% \mathrm{RH}(8$, 9). Later, Silva et al. (10) demonstrated that the L3 vertical migration on the forage is critical in the parasite transmission, allowing its ingestion by the grazing host. This migratory behavior is influenced by climatic conditions such as temperature, relative humidity, sunlight, and rainfall $(3,11-13)$.

$H$. contortus and $H$. placei have been reported in Colombian herds since 1983 (14). Researches on the parasite ecology has been conducted in different agroclimatic zones (15-19). In a 4-year study using weaned calves, Parra and Uribe (20) found a high level of pasture infestation with Haemonchus sp. larvae associated with periods of high rainfall (April to June, and August to September) in the piedmont (foothills) of the eastern Colombian plains.

Worldwide, this parasitosis control has been implemented since the 19th century, mainly using regular pharmaceutical compounds. Nevertheless, due to these products' unsupervised dosage regimes, the parasitic organisms have developed resistance (1, 21-23). Consequently, FAO recommends developing sustainable pest control strategies in animal production systems (e.g., against gastrointestinal parasites); sustainable from the environmental perspective and long-time effective from the animal health perspective (24). Thus, based on the large numbers of ethnopharmacological reports, the research on medicinal plant extracts for parasite control has become a widely distributed scientific practice that had yield relevant findings for integrated pest management practice (25-28). Moreover, the use of plant extracts can have less impact on the environment due to their short biodegradation time in the soil compared to traditional pharmaceutical compounds (29).

Various types of traditional plants for medical use have been studied to obtain extracts that present potential antiparasitic activity. Hence, the anthelmintic activity of $M$. charantia has been registered in in-vitro and in-vivo trials and by phytochemical analyses in other latitudes (30-32). M. charantia is known as "the bitter melon" and belongs to the Cucurbitaceae family (33). The plant grows in tropical areas of Asia, Amazon, East Africa, and the Caribbean. It is cultivated throughout the world as a food source and for medicinal purposes (34). 
M. charantia has been used traditionally as a medicinal plant in different countries such as Brazil, China, Cuba, Ghana, Haiti, India, México, Malaysia, New Zealand, Nicaragua, Panamá Perú, and Colombia (35-37). Some reports have already described the exploration of the potential effects of $M$. charantia extracts for the control of $H$. contortus in small ruminants (38-40). In this regard, the anthelmintic capacity of $M$. charantia has been attributed to different secondary metabolites such as the triterpene compound called cucurbitacin $B$, the non-protein amino acid called cucurbitin (3-aminopyrrolidine-3-carboxylic acid), many saponins, and various sterols $(41,42)$. Other compounds such as cucurmosin (ribosome-inactivating protein) found in stem and leaves have also been studied (43).

The objective of this study was to evaluate the in-vitro effect of the methanolic extract of $M$. charantia on the hatching process of Haemonchus sp. nematode as a potential therapeutic alternative for integrated parasite management programs in sheep production systems of the piedmont region in Meta, Colombia.

\section{MATERIALS AND METHODS}

\section{Methanolic extract preparation}

$10 \mathrm{Kg}$ of $M$. charantia leaves were collected in the Barcelona farm of Universidad de Los Llanos (Villavicencio, Meta, Colombia) during February (dry season). A sample of the leaf, stem, and fruitflowering was sent to the Colombian National Herbarium to perform a taxonomic classification. The methanolic extract was made from $M$. charantia leaves, dried in a recirculating air oven at $40^{\circ} \mathrm{C}$ for 72 hours. Then, the dry material was pulverized, obtaining a homogeneous sifting. The material was percolated continually until exhaustion with methanol 98\% (Merck ${ }^{\circledR}$, Germany). The percolated liquid was filtered and concentrated at $40^{\circ} \mathrm{C}$ using a Roto-evaporator (IKA ${ }^{\circledR}$, Brazil). The resulting extract was reconstituted in $0.5 \%$ dimethyl sulfoxide solution (DMSO) (Merck ${ }^{\circledR}$, Germany) to 10, 20, 40, 80, and 160 $\mathrm{mg} / \mathrm{mL}$ concentrations for the in-vitro tests, following the methodology proposed by Domingues et al. (28).

\section{Egg hatch inhibition test}

Following the Michael et al. (45) methodology, eggs of Haemonchus sp. were obtained from $20 \mathrm{~g}$ of feces taken from the rectal ampulla of a monoinfected sheep. Its collection and concentration were performed using different sieves $(1 \mathrm{~mm}, 106 \mu \mathrm{m}$,
$53 \mu \mathrm{m}$, and $25 \mu \mathrm{m}$ mesh) according to the method published by Bizimenyera et al. (46) based on the original method reported by Coles et al. (47). The effect of the extract in eggs was evaluated according to the guidelines proposed by the WAAVP (World Association for the Advancement of Veterinary Parasitology) and described by Powers et al. (48). Briefly, approximately 100 eggs were exposed (250 $\mu \mathrm{L}$ final volume) to the five treatment levels of the methanolic extract of $M$. charantia, to $25 \mu \mathrm{g} / \mathrm{mL}$ of Albendazole (Sigma ${ }^{\circledR}$, Germany; positive control), and $0.5 \%$ DMSO (negative control) (Table1). Each test was replicated five times; all tests were performed 24 hours at $27^{\circ} \mathrm{C}$ and $\mathrm{RH}>80 \%$. After that, a drop of Lugol's lodine solution (PipingRock ${ }^{\circledR}$, U.S.A.) was added to stop the hatching process. Larvae (L1) and eggs were counted using an inverted microscope (Leica ${ }^{\circledR}$, Germany). The hatching inhibition percentage (HI \%) was determined for each level of treatment with the following formula: $\mathrm{HI} \%=100$ ( $\mathrm{P}$ test $/ \mathrm{P}$ total), where "P test" is the number of eggs and "P total" is the number of eggs plus the count of L1 individuals. This research was approved by the General Director of Research of the Universidad de Los Llanos through the project "Alternativa terapéutica para el control de la haemoncosis con base en el extracto metanólico de Momordica charantia en sistemas de producción bovina del piedemonte del departamento del Meta" according to announcement 01-P-2013, which guarantees the humane treatment of the experimental animals used.

\section{Preliminary phytochemical screening}

The preliminary phytochemical analysis of $M$. charantia leaves was conducted following the colorimetric methods and thin-layer chromatography methodology proposed by Sanabria (44). These methods permit the detection of alkaloids, steroids or triterpenoids, flavonoids, naphthokines or anthraquinones, tannins, lactones, coumarins, and other cardiotonics.

\section{Statistical analyses}

The hatching inhibition values obtained are presented as hatching inhibition percentages and were compared to the negative control group (DMSO $0.5 \%)$ using the Chi-square test for comparing two proportions distributions $(p<0,05)$. The $\mathrm{LC}_{50}$ and $\mathrm{LC}_{90}$ were estimated from egg hatching inhibition results through the Probit regression model analysis (estimate plus 95\% confidence interval). The data were organized and analyzed with OpenStat 4.0, version 7.0 statistical program. 


\section{RESULTS}

The methanolic extract of $M$. charantia showed satisfactory hatching inhibition results on Haemonchus sp. eggs (Table 1). Concentrations from 1 to $8 \%$ (10 to $80 \mathrm{mg} / \mathrm{mL}$ ) showed significant differences with the DMSO $0.5 \%$ negative control group $\left(\chi^{2}=0.024\right.$, $p$-value $\left.<0.05\right)$. Likewise, inhibitory action to the hatching of Haemonchus sp. eggs in the concentration of $16 \%(160 \mathrm{mg} / \mathrm{mL})$ of the plant extract was similar to the Albendazole $25 \mu \mathrm{g} / \mathrm{mL}$ control group. We also found significant differences in hatching inhibition percentages ( $p$-value < 0.001 ) to DMSO $0.5 \%$. For this study, according to the Probit regression results, the $\mathrm{LC}_{50}$ estimated was $52.18 \mathrm{mg} / \mathrm{mL}$ (95\% Cl: 37.87 - 63.22), and the estimated $\mathrm{LC}_{90}$ was $201.45 \mathrm{mg} / \mathrm{mL}(95 \% \mathrm{Cl}$ : 186.01 - 221.89).

Table 1. Inhibition effect on the hatching of Haemonchus sp. exposed to the methanolic extract of $M$. charantia.

\begin{tabular}{lc}
\hline Extract concentration - controls & \% Hatching inhibition \\
\hline $10 \mathrm{mg} / \mathrm{mL}$ & $38.3 \%^{\mathrm{A}}$ \\
$20 \mathrm{mg} / \mathrm{mL}$ & $24.2 \%^{\mathrm{A}}$ \\
$40 \mathrm{mg} / \mathrm{mL}$ & $34.5 \%^{\mathrm{A}}$ \\
$80 \mathrm{mg} / \mathrm{mL}$ & $50.4 \%^{\mathrm{A}}$ \\
$160 \mathrm{mg} / \mathrm{mL}$ & $84.6 \%^{\mathrm{B}}$ \\
Albendazole $25 \mu \mathrm{g} / \mathrm{mL}$ & $100 \%^{\mathrm{B}}$ \\
DMSO $5 \mathrm{mg} / \mathrm{mL}$ & $0 \%$ \\
\hline
\end{tabular}

Different superscript letters in the same column indicate significant differences comparing to the level of DMSO $0.5 \%$ negative control treatment, Chi-square test. A $p<0.05, B$ p $<0.001$.

Table 2, presents the characterization of secondary metabolites groups in the methanolic extract of $M$. charantia, obtained by qualitative techniques of colorimetry and thin-layer chromatography. These techniques allowed us to characterize alkaloids, triterpenes, and anthracenic glucosides.

\section{DISCUSSION}

M. charantia has been used in traditional medicine (30-32, 34-37). The phytochemical assets of its extracts have been appraised due to antibacterial $(49,50)$, anticancer $(51,52)$, antidiabetic $(53,54)$, antidepressant $(55)$, antifungal $(56,57)$, antiviral (58), and anthelmintic (30-32, 59-62) properties, among others. Likewise, nutritional analyses of $M$. charantia indicate that this plant is rich in fiber, calcium, potassium, iron, and vitamins $A$ and $C$ (63). The pulp around the ripe fruit seeds is a good source of carotenoid lycopene (64). Besides, M. charantia is an important source of phenolic compounds with high antioxidant and antimutagenic properties (65).

The plant extracts action mechanisms can affect different stages of the Haemonchus sp. life cycle, including the free-living phase (pre-parasitic) and either the L3 infective and parasitic phases. The antihelmintic effect of cucurbits is related to the presence of hydrolases in $M$. charantia capable of binding to the parasite's cuticle, activating a proteinase enzymatic complex that promotes the digestion of the parasite's cuticle, finally causing the death of the parasite (78-80). Regarding the results of our study, the catalytic activity of the anthracenic glycosides found in M. charantia (Table 2) could be responsible for the degradation of the Haemonchus sp. eggshell membrane. It may play a central role in the antiparasitic activity (81). However, further research is necessary to elaborate elucidation of the chemical processes involved.

Beloin et al. (82) worked with different extracts of M. charantia leaves and found a direct anthelmintic effect of momordicins (saponins) and triterpenes on Caenorhabditis elegans (nematode) using a $500 \mathrm{mg} / \mathrm{mL}$ lethal concentration. Similar results were reported in a study by Ling et al. (83). They

Table 2. Characterization of the groups of secondary metabolites in the methanolic extract of $M$. charantia.

\begin{tabular}{llc}
\hline Groups of secondary metabolites & Colorimetric test /result & Thin-layer chromatography - Pure samples/result \\
\hline \multirow{2}{*}{ Alkaloids } & Mayer's reagent (-) & \\
& $\begin{array}{l}\text { Ammonium reineckate }(-) \\
\text { Dragendorf's reagent (+) } \\
\text { Valser's reagent (-) }\end{array}$ & Quinidine (+) \\
\hline Flavonoids & Shinoda's reagent (-) & Flavone (-) \\
\hline Triterpenes & $\mathrm{NA}$ & $(+)$ \\
\hline Anthracenic glucosides & $\mathrm{NaOH} 5 \% \mathrm{NH}_{4} 2 \%(+)$ & Sacred Cascara (-) \\
\hline Cardiogenic glucosides & Kedde's reaction (-) & Digitalina (-) \\
\hline
\end{tabular}

(-): Absence, (+): Presence, NA: not applied. 
found momordicins in an ethanolic extract of $M$. charantia, and demonstrated the adverse effects on the feeding processes of the L2 and L3 stages of Plutella xylostella (a pest of ornamental crops). They also reported lethal larval concentrations of momordicin II of 76,69 , and $116.24 \mathrm{mg} / \mathrm{mL}$, respectively. Other effects reported were inhibition of weight gain and reduced larval survival.

Studies by Islam et al. (84) used aqueous methanolic and ethanolic extracts of $M$. charantia leaves, showing effects on the hatching of Ascaridia galli eggs. Using a concentration of $4 \%$ of the extract, they reported $70 \%$ and $67 \%$ eggs development adverse effects with the aqueous extract and $65 \%$ with the methanolic extract. These results indicated that a higher concentration was needed and support the concentration used in the present study (16\%) to achieve similar results to the positive control (Table 1).

Tjokropranoto and Nathania (59) studied the effect of $M$. charantia in adult nematodes. From an in-vivo experiment in pigs, they reported that after treatments with an ethanolic extract of $M$. charantia leaves at concentrations of $10 \%, 20 \%$, and $40 \%$, the average percentage of Ascaris suum that were paralyzed or killed was $75 \%, 83 \%$, and $88 \%$ respectively. Likewise, Chastity et al. (60) studied an ethanolic extract of $M$. charantia leaves to estimate the mortality rate on Ascaris suum. They found that the adult nematodes mortality time was 10 hours, with the $80 \%$ extract concentration compared to the 4 hours required using pyrantel pamoate (positive control). Besides, Shahadat et al. (61) y Alam et al. (62) studied the effect of aqueous extracts of $M$. charantia on Ascardia galli affecting broilers. They found very high mortality rates $(75 \%$ and $95 \%$, respectively) using concentrations up to $100 \mathrm{mg} /$ $\mathrm{mL}$. This high concentration was chosen to induce short-term mortalities. From the studies described, it is inferred that more studies are needed on the effect of $M$. charantia extract in adult and larval stages of Haemonchus sp.

We confirmed the presence of terpenes, alkaloids, and anthraquinone glycosides, which are important secondary metabolites attributed to $M$. charantia with antihelmintic potential (Table 2). These compounds have been reported for this purpose by Poolperm and Jiraungkoorskul (30), Morton (43), and Bauri et al. (66). These secondary metabolites can also be found in other medicinal plants with anthelmintic activity: terpenes (67-72), alkaloids (73-75), and glycosides (67, 70, 73, 76). However, flavonoids, other anthelmintic metabolites described in M. charantia were not detected by our techniques $(66,77)$.

The scientific inferences exposed in this study, similar to others in the detection of secondary metabolites groups of and describing their anthelmintic effects, confirm the potential of $M$. charantia extracts as beneficial compounds to be part of the integrated parasite control programs in livestock production systems in the tropics.

\section{CONCLUSIONS}

In the in-vitro test, the methanolic extract of $M$. charantia effectively inhibited the hatching of Haemonchus sp. The presence of secondary metabolites like alkaloids, triterpenes, and anthracene glucosides was detected in the methanolic extract of $M$. charantia (under the given collection period, location, and conditions).

It is necessary to develop a process of bio-guided fractionation of the methanolic extract of $M$. charantia in order further to purify the relevant compounds and evaluate its biological activity on different life stages of $H$. contortus; this being a plant species widely adapted to the conditions of the piedmont (foothills) of Meta, Colombia.

\section{CONFLICTS OF INTEREST}

The authors declare no conflict of interest.

\section{ACKNOWLEDGMENTS}

Kelly V. Martínez for her support and collaboration in animal care and welfare assurance and her experimental phase contributions.

\section{AUTHOR CONTRIBUTIONS}

Conceptualization: DAJ; methodology: DAJ and $A V$; DAJ and AV; writing (original draft preparation) DAJ and AV; Review and editing, DAJ, AV, and LCL. All authors have read and agreed to the published version of the manuscript.

\section{REFERENCES}

1. Drudge J, Szanto J, Wyant Z, Elam G. Field studies on parasite control in sheep: comparison of thiabendazole, ruelene, and phenothiazine. Am. J. Vet. Res [Internet]. 1964;25:15121518. Available from: https://www.scienceopen.com/ document?vid=1571be24-967d-4592-b8fd-c9ae1d5196ec 
2. Grisi L. O problema de parasitismo interno dos bovinos nos tropicos. Seminario internacional: Manejo y control de ecto y endoparásitos en ganado bovino, Convenio ICA-GTZ-Unisalle, Cartagena de Indias; 1993.

3. Agyei A. Seasonal changes in the level of infective strongylate nematodes larvae on pasture in the coastal savanna regions of Ghana. Vet. Parasitol. 1997;70:175-182. DOI: https://doi. org/10.1016/S0304-4017(96)01101-6

4. Marquéz D. Nuevas tendencias para el control de los parásitos de bovinos en Colombia. Corpoica. Bogotá D.C. 2003, 1-52p

5. Charlier J, Höglund J, Dorny P, von Samson-Himmelstjerna G, Vercruysse, J. Gastrointestinal nematode infections in adult dairy cattle: impact on production, diagnosis and control. Vet. Parasitol. 2009;164:70-79. DOI: https://doi.org/10.1016/j.vetpar.2009.04.012

6. O'Connor L, Walkden S, Kahn L. Ecology of the free-living stages of major trichostrongylid parasites of sheep. Vet. Parasitol. 2006;142:1-15. DOI: https://doi.org/10.1016/j.vetpar.2006.08.035

7. Ueno $\mathrm{H}$, Gonçalves P. Manual para diagnóstico das helmintoses de ruminantes, fourth ed., Japan International Cooperation Agency, Tokyo; 1998.

8. Prichard R. Genetic variability following selection of Haemonchus contortus with anthelmintics. Trends Parasitol. 2001;17:445-453. DOI: https://doi.org/10.1016/s1471-4922(01)01983-3

9. Stromberg B, Gasbarre L. Gastrointestinal Nematode Control Programs with an Emphasis on Cattle. Vet Clin Food Anim. 2006;22:543-565. DOI: https://doi.org/10.1016/j.cvfa.2006.08.003

10. Silva B, Amarante M, Kadri S, Carrijo-Mauad J. Amarante A. Vertical migration of Haemonchus contortus third stage larvae on Brachiaria decumbens grass. Vet. Parasitol. 2008;158:85-92. DOI: https://doi.org/10.1016/j.vetpar.2008.08.009

11. Callinan A, Westcott J. Vertical distribution of trichostrongylid larvae on herbage and in soil. Int. J. Parasitol. 1986;16:241-244. DOI: https://doi.org/10.1016/0020-7519(86)90050-0

12. Silangwa S, Todd A. Vertical migration of Trichostrongylid larvae on grasses. J. Parasitol. 1964;50:278-285. DOI: https://doi. org/10.2307/3276286

13. Hoberg E, Lichtenfels J, Gibbons L. Phylogeny for species of Haemonchus (Nematoda: Trichostrongyloidea): considerations of their evolutionary history and global biogeography among Camelidae and Pecora (Artiodactyla). J. Parasitol. 2004;90:10851102. DOI: https://doi.org/10.1645/ge-3309

14. Rivera B, Parra D, García O, Aycardi E. Gastro-intestinal parasites in calves in Colombia. Tropical Animal Health and Production [Internet]. 1983;15:107-114. Available from: https://link.springer. com/article/10.1007/BF02239806

15. Pinilla J, Florez P, Sierra $M$, Morales E, Sierra R, Vásquez $M$, et al. Prevalencia del parasitismo gastrointestinal en bovinos del Departamento del Cesar, Colombia. Rev. Inv. Perú. 2018;29:278287. DOI: http://dx.doi.org/10.15381/rivep.v29i1.14202

16. Tullner F, Roqueme L, Otte J. Investigaciones sobre la ocurrencia, epidemiología, e importancia económica de los helmintos en terneros en el departamento de Córdoba, Colombia, ICA-GTZ, Informe Técnico $N^{\circ} 10$, Bogotá; 1993; 1-58p

17. Marquéz D, Jaramillo F, Romero A. Dinámica del parasitismo gastrointestinal en bovinos del hato de Tibaitata, Colombia. Revista de medicina Veterinaria y Zootecnia. Universidad Nacional de Colombia. 2000;47:49-56.

18. Herrera L, Ríos L, Zapata R. Frecuencia de la infección por nemátodos gastrointestinales en ovinos y caprinos de cinco municipios de Antioquia. Rev. MVZ Córdoba. 2013;18:3852-2860. DOI: https://doi.org/10.21897/rmvz.157
19. Marquéz D, García F, Jiménez G, Garzón C, Alarcón R, Basto G, et al. Diseño y estrategias para el control de ecto y endoparásitos del ganado en trópicos medio, bajo y de altura, de Cundinamarca y Boyacá. Informe Técnico Final Pronatta. Bogotá D.C. 2003.

20. Parra D, Uribe L. Epidemiología de nematodos del bovino en el pidedemonte de los Llanos Orientales de Colombia. Rev. ACOVEZ. 1993;14:16-25.

21. Lichtenfels J, Pilitt P, Hoberg E. New morphological characters for identifying individual specimens of Haemonchus spp. (Nematoda: Trichostrongyloidea) and a key to species in ruminants of North America. J. Parasitol. 1994;80:107-119. DOI: https://doi. org $/ 10.2307 / 3283353$

22. Cruz D, Rocha L, Arruda S, Palieraqui J, Cordeiro R, Santos Junior $E$, Molento $M$, et al. Anthelmintic efficacy and management practices in sheep farms from the state of Rio de Janeiro, Brazil. Vet. Parasitol. 2010;170:340-343. DOI: https://doi.org/10.1016/j. vetpar.2010.02.030

23. Brasil B, Nunes R, Bastianetto E, Drummond M, Carvalho D, Leite R, et al. Genetic diversity patterns of Haemonchus placei and Haemonchus contortus populations isolated from domestic ruminants in Brazil. International Journal for Parasitology. 2012;42:469-479. DOI: https://doi.org/10.1016/j. ijpara.2012.03.003

24. Food and Agriculture Organization of the United Nations. Resistance Management and Integrated Parasite Control in Ruminants: Guidelines, first ed, FAO Animal Production and Health Division. Agricultural Dept, Rome; 2004.

25. Rojas D, López J, Tejada I, Vázquez V, Shimada A, Sánchez D, et al. Impact of condensed tannins from tropical forages on Haemonchus contortus burdens in Mongolian gerbils (Meriones unguiculatus) and Pelibuey lambs. Anim. Feed Sci. Technol. 2006;128:218-228. DOI: https://doi.org/10.1016/j.anifeedsci.2005.10.008

26. Alonso M, Torres J, Sandoval C, Hoste H, Aguilar A. In vitro larval migration and kinetics of exsheathment of Haemonchus contortus larvae exposed to four tropical tanniniferous plant extracts. Vet. Parasitol. 2008;153:313-319. DOI: https://doi.org/10.1016/j. vetpar.2008.01.042

27. Minho A, Bueno I, Louvandini H, Jackson F, Gennari S, Abdalla A. Effect of Acacia molissima tannin extract on the control of gastrointestinal parasites in sheep. Anim. Feed Sci. Technol. 2008;147:172-181. DOI: https://doi.org/10.1016/j. anifeedsci.2007.09.016

28. Domingues L, Giglioti R, Feitosa K, Fantatto R, Rabelo M, Oliveira $M$, et al. In vitro and in vivo evaluation of the activity of pineapple (Ananas comosus) on Haemonchus contortus in Santa Inês sheep. Vet. Parasitol. 2013;197:263-270. DOI: https://doi.org/10.1016/j. vetpar.2013.04.031

29. Ribeiro V, Avancini C, Gonçalves K, Toigo E, von Poser G. Acaricidal activity of Calea serrata (Asteraceae) on Boophilus microplus and Rhipicephalus sanguineus. Vet. Parasitol. 2008;15:351-354. DOI: https://doi.org/10.1016/j.vetpar.2007.11.007

30. Poolperm S, Jiraungkoorskul W. An Update Review on the Anthelmintic Activity of Bitter Gourd, Momordica charantia. Pharmacogn. Rev. 2017;11:31-34. DOI: https://doi.org/10.4103/ phrev.phrev_52_16

31. Andrade K, Duque D, Jaramillo D. Momordica charantia como alternativa terapéutica en la medicina veterinaria. Rev. Sist. Prod. Agroecol. 2012;3:15-35. DOI: https://doi.org/10.18387/ polibotanica.41.6

32. Grover J, Yadav S. Pharmacological actions and potential uses of Momordica charantia: A review. Journal of Ethnopharmacology. 2004;93:123-132. DOI: https://doi.org/10.1016/j.jep.2004.03.035 
33. Integrated Taxonomic Information System (ITIS). Momordica charantia. Taxonomic Serial No.:22399. Geological Survey, VA, USA; 2016.

34. Kritikar K, Basu B. Indian Medicinal Plants. The Indian Press, Allahabad. 1918; Volume 1, 590p.

35. Giron L, Freire V, Alonzo A, Caceres A. Ethnobotanical survey of the medicinal flora used by the Caribs of Guatemala. Journal of Ethnopharmacology. 1991;34:173-187. DOI: https://doi. org/10.1016/0378-8741(91)90035-C

36. Lans C, Brown G. Observations on ethnoveterinary medicines in Trinidad and Tobago. Preventive Veterinary Medicine. 1998;35:125142. DOI: https://doi.org/10.1016/S0167-5877(97)00055-X

37. Satyawati G, Gupta A, Tandon N. Medicinal plants of India. first ed, Indian Council of Medical Research, New Delhi, 1987, 262p

38. Achi YL, Zinsstag J, Yao K, Yeo N, Dorchies P, Jacquiet P. Host specificity of Haemonchus spp. for domestic ruminants in the savanna in northern Ivory Coast. Vet. Parasitol. 2003;116:151-158. DOI: https://doi.org/10.1016/s0304-4017(03)00258-9

39. Vieira L, Cavalcante A, Pereira, M, Dantas L, Ximenes L. Evaluation of anthelmintic efficacy of plants available in Ceara State, northeast Brazil, for the control of goat gastrointestinal nematodes. Rev. Med. Vet [Internet]. 1999;150:447-452. Available from: https:// www.revmedvet.com/artdes-us.php?id=53

40. Githiori J, Athanasiadou S, Thamsborg S. Use of plants in novel approaches for control of gastrointestinal helminths in livestock with emphasis on small ruminants. Vet. Parasitol. 2006;139:308 320. DOI: https://doi.org/10.1016/j.vetpar.2006.04.021

41. Mihranian V, Abou C. Extraction, detection, and estimation of cucurbitin in Cucurbita seeds, J Lloydia [Internet]. 1968;31:23-29. Available from: https://eurekamag.com/ research/014/472/014472546.php

42. Okabe H, Miyahara Y, Yamauchi T. Studies on the constituents of Momordica Charantia L. Isolation and characterisation of momordicosides A and B, glycosides of a pentahydroxycucurbitane triterpene. Chem Pharm Bull. 1980;28:2753-2762. DOI: https://doi.org/10.1248/cpb.28.2753

43. Morton J. Atlas of Medicinal Plants of Middle America, first ed, Springfield, Illinois, 1981; $34-40 p$.

44. Sanabria A. Análisis fitoquímico preliminar. first ed, Universidad Nacional de Colombia, Facultad de Ciencias, Departamento de Farmacia, Bogotá, 1983; 1-61p

45. Michael B, Meinke P, Shoop W. Comparison of ivermectin, doramectin, selamectin, and eleven intermediates in a nematode larval development assay. J Parasitol. 2001;87:692-696. https://doi. org/10.1645/0022-3395(2001)087[0692:coidsa]2.0.co;2

46. Bizimenyera E, Githiori J, Eloff J, Swan G. In vitro activity of Peltophorum africanum Sond. (Fabaceae) extracts on the egg hatching and larval development of the parasitic nematode Trichostrongylus colubriformis. Vet. Parasitol. 2006;142:336-343. DOI: https://doi.org/10.1016/j.vetpar.2006.06.013

47. Coles G, Bauer C, Borgsteede F, Geerts S, Klei T, Taylor M, et al. World Association for the Advancement of Veterinary Parasitology (WAAVP) methods for the detection ofanthelmintic resistance in nematodes of veterinary importance. Vet. Parasitol. 1992;44:3544. DOI: https://doi.org/10.1016/0304-4017(92)90141-u

48. Powers KG, Wood I, Eckert J, Gibson T, Smith H. World associations of the advancement of veterinary parasitology (WAAVP) guidelines for evaluating the efficacy of anthelmintics in ruminants (bovine and ovine). Vet. Parasitol. 1982;10:265-284. DOI: https://doi. org/10.1016/0304-4017(82)90078-4

49. Costa J, Nascimento E, Campos A, Rodrigues F. Antibacterial activity of Momordica charantia (Curcubitaceae) extracts and fractions. J Basic Clin Pharm. 2010;2:45-51. DOI: http://www.ncbi. nlm.nih.gov/pmc/articles/pmc3979203/

50. Yaldiz G, Sekeroglu N, Kulak M, Demirkol G. Antimicrobial activity and agricultural properties of bitter melon (Momordica charantia L.) grown in northern parts of Turkey: A case study for adaptation. Nat Prod Res. 2015;29:543-545. DOI: https://doi.org/10.1080/147 86419.2014.949706

51. Pitchakarn $P$, Ogawa K, Suzuki S, Takahashi S, Asamoto M, Chewonarin T. Momordica charantia leaf extract suppresses rat prostate cancer progression in vitro and in vivo. Cancer Sci. 2010;101:2234-2240. DOI: https://doi.org/10.1111/j.13497006.2010.01669.x

52. Shobha C, Vishwanath $P$, Suma M, Prashant A, Rangaswamy $C$, Gowdappa B. In vitro anti-cancer activity of ethanolic extract of Momordica charantia on cervical and breast cancer cell lines. $\mathrm{J}$ of Health Allied Sci [Internet] 2015;4:210-217. Available from: https://www.researchgate.net/deref/http\%3A\%2F\%2Fdx.doi. org\%2F10.4103\%2F2278-344X.167649

53. Tahira S, Hussain F. Antidiabetic evaluation of Momordica charantia L fruit extracts. West Indian Med J. 2014;63:294-299. DOI: https://doi.org/10.7727/wimj.2013.180

54. Perumal V, Khoo W, Abdul-Hamid A, Ismail A, Saari K, Murugesu S. Evaluation of antidiabetic properties of Momordica charantia in streptozotocin Induced diabetic rats using metabolomics approach. J Food Res [Internet] 2015;22:1298-1306. Available from: https://www.researchgate.net/ publication/282198654_Evaluation_of_antidiabetic_properties_ of_Momordica_charantia_in_streptozotocin_induced_diabetic_ rats_using_metabolomics_approach

55. Meera S, Nagarjuna C. Antistress and immunomodulatory activity of aqueous extract of Momordica charantia. Pharmacogn Mag [Internet]. 2009;5:69-73. Available from: https://www.researchgate. net/publication/287479315_Antistress_and_immunomodulatory_ activity_of_aqueous_extract_of_Momordica_charantia

56. Gupta M, Sharma S, Bhadauria R. In vitro efficacy of Momordica charantia extracts against phytopathogenic fungi, Fusarium oxysporum. J Biopesticides [Internet] 2016;9:8-22. Available from: https://www.researchgate.net/publication/304956887_ In_vitro_efficacy_of_Momordica_charantia_extracts_against_ phytopathogenic_fungi_Fusarium_oxysporum

57. Wang S, Zheng Y, Xiang F, Li S, Yang, G. Antifungal activity of Momordica charantia seed extracts toward the pathogenic fungus Fusarium solani L. J Food Drug Anal [Internet]. 2016;24:881887. Available from: https://www.researchgate.net/deref/ http\%3A\%2F\%2Fdx.doi.org\%2F10.1016\%2Fj.jfda.2016.03.006

58. Puri M, Kaur I, Kanwar R, Gupta R, Chauhan A, Kanwar J. Ribosome inactivating proteins (RIPs) from Momordica charantia for anti viral therapy. Curr Mol Med. 2009;9:1080-1094. DOI: https://doi. org/10.2174/156652409789839071

59. Tjokropranoto R, Nathania M. Anthelmintic effect of ethanol extract of pare leaf (Momordica charantia L.) against female Ascaris suum worm in vitro. J Med Planta [Internet]. 2011;1:3339. Available from: https://www.neliti.com/publications/245875/ anthelmintic-effect-of-ethanol-extract-of-pare-leaf-momordicacharantia-l-agains

60. Chastity C, Yuwono K, Utami U, PralaAyu A, Priscillah W, Sutrisna $E$. The anthelmintics effect of Momordica charantia L. leaves and Andrographis paniculata Ness. from Indonesia. Int J Ayurveda Pharm Res [Internet]. 2015;3:33-9. Available from: https://ijapr.in/ index.php/ijapr/article/view/127

61. Shahadat H, Mostofa, M.; Mamun, M.; Hoque, M.; Awal, M. Comparative efficacy of korolla (Momordica charantia) extract and

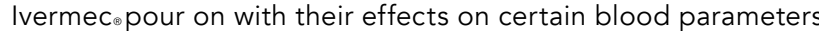
and body weight gain in indigenous chicken infected with 
Ascaridia galli. Bangladesh J Vet Med. 2008;6:153-158. DOI: https://doi.org/10.1016/j.vetpar.2007.05.015

62. Alam M, Alam K, Begum N, Amin M. Comparative efficacy of different herbal and modern anthelmintics against gastrointestinal nematodiasis in fowl. J Biol Res [Internet]. 2014;2:145-148. Available from: https://www.sciencepubco.com/index.php/IJBR/ article/view/3584

63. USDA Composition of Foods Raw, Processed, Prepared USDA. National Nutrient Database for Standard Reference, Release 21, US Department of Agriculture, Maryland; 2008.

64. Wang L, Wang M, Li Q, Cai T, Jiang W. Partial properties of an aspartic protease in bitter gourd (Momordica charantia L.) fruit and its activation by heating. Food Chem. 2008;108:496-502. DOI: https://doi.org/10.1016/j.foodchem.2007.10.085

65. Islam S, Jalaluddin M, Hettiarachchy N. Bio-active compounds of bitter melongenotypes (Momordica charantia L.) in relation to their physiological functions. Functional Foods in Health \& Disease. 2011;2:61-74. DOI: https://doi.org/10.31989/ffhd.v1i2.139

66. Bauri R, Tigga M, Kullu S. A review on use of medicinal plants to control parasites. Indian J Nat Prod Resour. [Internet] 2015;6:268-277. Available from: https://www.researchgate.net/ publication/292161550_A_review_on_use_of_medicinal_plants_ to_control_parasites

67. Aleman Y, Ferreira L, Pino O, Dias M, Roque E.; de Souza A. Anthelmintic activity in vitro of Citrus sinensis and Melaleuca quinquenervia essential oil from Cuba on Haemonchus contortus. Industrial Crops and Products. 2015;76:647-652. DOI: https://doi. org/10.1016/j.indcrop.2015.07.056

68. Cavalcante G, de Morais S, Andre W, Ribeiro W. Rodrigues A, De Lira F, et al. Chemical composition and in vitro activity of $Q^{\text {aa }}$ (Ait.) latex on Haemonchus contortus. Vet. Parasitol. 2016;226:22-25. DOI: https://doi.org/10.1016/j.vetpar.2016.06.012

69. Zhu L, Dai J, Yang L, Qiu J. In vitro ovicidal and larvicidal activity of the essential oil of Artemisia lancea against Haemonchus contortus (Strongylida). Vet Parasitol. 2013;195:112-117. DOI: https://doi. org/10.1016/j.vetpar.2012.12.050

70. Minho A, Domingues L, Gainza Y, Figueiredo A, Boligon $A$, Domingues $R$, et al. In vitro screening of plant extract on Haemonchus contortus and Rhipicephalus (Boophilus) microplus. Journal of Essential Oil Research. 2020;32:269-278. DOI: https://www.researchgate.net/deref/http\%3A\%2F\%2Fdx.doi.org \%2F10.1080\%2F10412905.2020.1746414

71. Carvalho C, Chagas A, Cotinguiba F, Furlan M, Brito L, Chaves $F$, et al. The anthelmintic effect of plant extracts on Haemonchus contortus and Strongyloides venezuelensis. Vet Parasitol. 2012;183:260-268. DOI: https://doi.org/10.1016/j. vetpar.2011.07.051

72. Ferreira L, Benincasa B, Fachin A, Franca S, Contini S, Chagas A, et al. Thymus vulgaris $\mathrm{L}$. essential oil and its main component thymol: Anthelmintic effects against Haemonchus contortus from sheep. Vet Parasitol, 2016;228:70-76. DOl: https://doi.org/10.1016/j. vetpar.2016.08.011
73. Kanojiya D. Shanker D, Sudan V, Jaiswal A, Parashar R. Anthelmintic activity of Ocimum sanctum leaf extract against ovine gastrointestinal activity of nematodes in India. Research in Veterinary Science. 2015;99:165-170. DOI: https://doi. org/10.1016/j.rvsc.2015.01.017

74. Eguale T, Tilahun G, Debella A, Feleke A, Makonnen E. Haemonchus contortus: In vitro and in vivo anthelmintic activity of aqueous and hydro-alcoholic extracts of Hedera helix. Experimental Parasitology. 2007;116:340-345. DOI: https://doi. org/10.1016/j.exppara.2007.01.019

75. Davuluri T, Chennuru S, Pathipati M, Krovvidi S, Rao G. In Vitro Anthelmintic Activity of Three Tropical Plant Extracts on Haemonchus contortus. Acta Parasit. 2019;65:11-18. DOI: https:// dx.doi.org/10.2478/s11686-019-00116-x

76. Mengistu G, Hoste H, Karonen M, Salminen J, Hendriks W, Pellikaan $W$. The in vitro anthelmintic properties of browse plant species against Haemonchus contortus is determined by the polyphenol content and composition. Vet Parasitol. 2017;237:110-116. DOI: https://doi.org/10.1016/j.vetpar.2016.12.020

77. Shan B, Xie J, Zhu J, Peng Y. Ethanol modified supercritical carbon dioxide extraction of flavonoids from Momordica charantia $L$. and its antioxidant activity. Food Bioproducts Process. 2012;90:579587. DOI: https://doi.org/10.1016/j.fbp.2011.09.004

78. Chaudary F, Qayyum M, Miller J. Development and survival of Haemonchus contortus infective larvae derived from sheep faeces under sub-tropical conditions in the Potohar region of Pakistan. Trop. Anim. Health Prod. 2008;40:85-92. DOI: https:// doi.org/10.1007/s11250-007-9037-x

79. Stepek G, Behnke J, Buttle D, Duce I. Natural plant cysteine proteinases as anthelmintic? Trends Parasitol. 2004;20:322-327. DOI: https://doi.org/10.1016/j.pt.2004.05.003

80. Buttle D, Behnke J, Bartley Y, Elsheikha H. Bartley D, Garnett M, et al. Oral dosing with papaya latex is an effective anthelmintic treatment for sheep infected with Haemonchus contortus. Parasite Vector. 2011;4:1-11. DOI: https://doi.org/10.1186/1756-3305-4-36

81. Mansfield L, Gamble H, Fetterer R. Characterization of the eggshell of Haemonchus contortus-I. Structural components. Comp. Biochem. Physiol. 1992;103:681-686. DOI: https://doi. org/10.1016/0305-0491(92)90390-D

82. Beloin N, Gbeassor M, Akpagana K, Hudson J, Soussa K, Koumaglo K, et al. Ethnomedicinal uses of Momordica charantia (Cucurbitaceae) in Togo and relation to its phytochemistry and biological activity. Journal of Ethnopharmacology. 2005;96:49-55. DOI: https://doi.org/10.1016/j.jep.2004.08.009

83. Ling B, Wang G, Ya J, Zhang M, Liang G. Antifeedant activity and active ingredients against Plutella xylostella from Momordica charantia leaves. Agricultural Sciences in China. 2008;7:1466-1473. DOI: https://doi.org/10.1016/S1671-2927(08)60404-6

84. Islam K, Farjana T, Begum N, Mondal M. In vitro efficacy of some indigenous plants on the inhibition of development of eggs of Ascaridia galli (Digenia: Nematoda). Bangladesh J. Vet. Med. 2008;6:159-167. DOI: http://dx.doi.org/10.3329/bjvm.v6i2.2330 